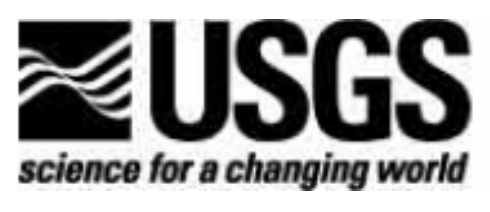

\title{
Coastal Vulnerability Assessment of Golden Gate National Recreation Area to Sea-Level Rise
}

By Elizabeth A. Pendleton, E. Robert Thieler, and S. Jeffress Williams

Any use of trade, firm, or product names is for descriptive purposes only and does not imply endorsement by the U.S. Government

\section{Open-File Report 2005-1058}

2005

U.S. Department of the Interior U.S. Geological Survey 


\title{
U.S. Department of the Interior
}

\author{
Gale A. Norton, Secretary
}

\section{U.S. Geological Survey \\ P. Patrick Leahy, Director}

\author{
U.S. Geological Survey, Reston, Virginia \\ For Additional Information: \\ See the National Park Unit Coastal Vulnerability study at http://woodshole.er.usgs.gov/project-pages/nps-cvi/, \\ the National Coastal Vulnerability study at http://woodshole.er.usgs.gov/project-pages/cvi/, \\ or view the USGS online fact sheet for this project in PDF format at http://pubs.usgs.gov/fs/fs095-02/. \\ To visit Golden Gate National Recreation Area Web site go to http://www.nps.gov/goga/index.htm. \\ Contact: \\ http://woodshole.er.usgs.gov/project-pages/nps-cvi/ Telephone: 508-548-8700 \\ Rebecca Beavers \\ National Park Service \\ Natural Resource Program Center \\ Geologic Resources Division \\ P.0. Box 25287 \\ Denver, CO 80225-0287 \\ Rebecca_Beavers@nps.gov \\ Telephone: 303-987-6945
}

For more information on the USGS - the Federal source for science about the Earth, its natural and living resources, natural hazards, and the environment:

World Wide Web: http://www.usgs.gov

Telephone: 1-888-ASK-USGS

Although this report is in the public domain, permission must be secured from the individual copyright owners to reproduce any copyrighted material contained within this report. 


\section{Contents}

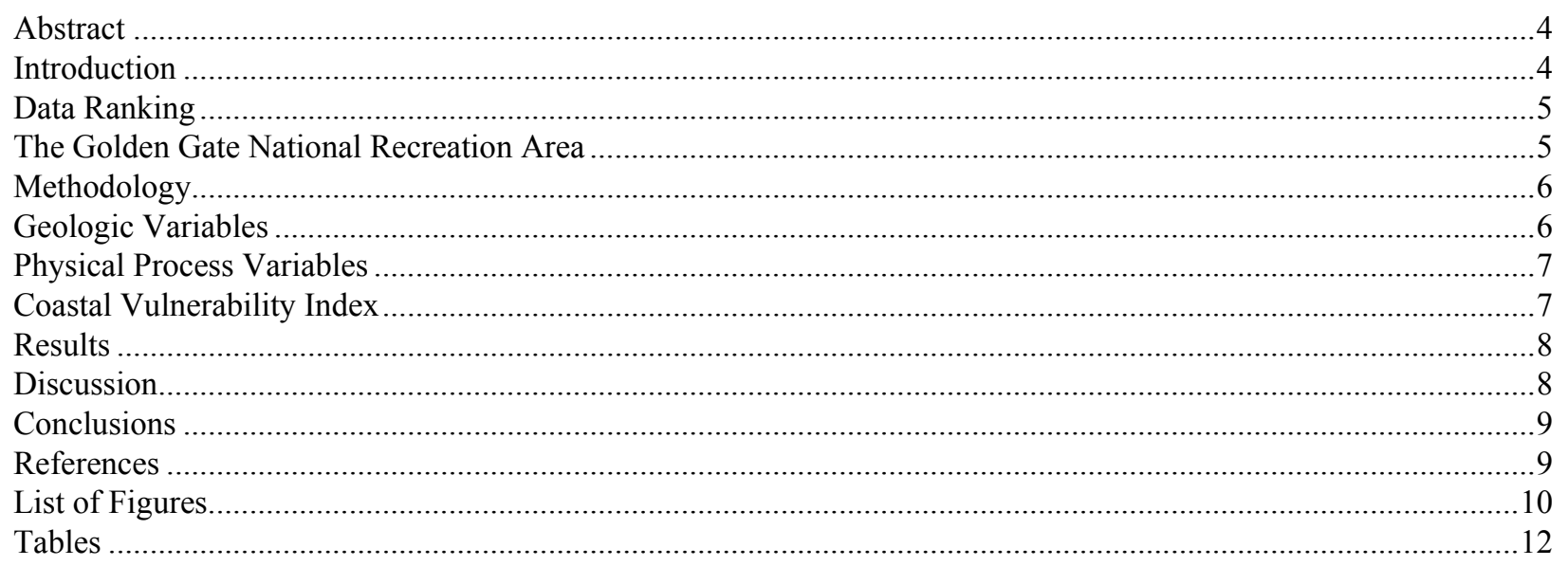




\title{
Coastal Vulnerability Assessment of Golden Gate National Recreation Area to Sea-Level Rise
}

\author{
By Elizabeth A. Pendleton, E. Robert Thieler, S. and Jeffress Williams
}

\begin{abstract}
A coastal vulnerability index (CVI) was used to map the relative vulnerability of the coast to future sealevel rise within the legislative boundary of Golden Gate National Recreation Area (GGNRA) in Northern California. The CVI ranks the following in terms of their physical contribution to sea-level rise-related coastal change: geomorphology, regional coastal slope, rate of relative sea-level rise, historical shoreline change rates, mean tidal range and mean significant wave height. The rankings for each input variable were combined, and an index value calculated for 1-minute grid cells covering the park. The CVI highlights those regions where the physical effects of sea-level rise might be the greatest. This approach combines the coastal system's susceptibility to change with its natural ability to adapt to changing environmental conditions, yielding a quantitative, although relative, measure of the park's natural vulnerability to the effects of sea-level rise. The CVI provides an objective technique for evaluation and long-term planning by scientists and park managers. The GGNRA coastlines consists of sand and gravel beaches, rock cliffs, sand dune cliffs, unconsolidated bluffs, and pocket beaches. The areas within GGNRA that are likely to be most vulnerable to sea-level rise are areas of unconsolidated sediment where shoreline erosion rates are high and wave energy is high.
\end{abstract}

\section{Introduction}

The National Park Service (NPS) is responsible for managing nearly 12,000 km (7,500 miles) of shoreline along oceans and lakes. In 2001, the U.S. Geological Survey (USGS), in partnership with the NPS Geologic Resources Division, began conducting hazard assessments of future sea-level change by creating maps to assist NPS in managing its valuable coastal resources. This report presents the results of a vulnerability assessment for GGNRA , highlighting areas that are likely to be most affected by future sea-level rise.

Global sea level has risen approximately 18 centimeters (7.1 inches) in the past century (Douglas, 1997). Climate models predict an additional rise of $48 \mathrm{~cm}$ (18.9 in.) by 2100 (IPCC, 2001), which is more than double the rate of rise for the 20th century. Potential coastal impacts of sea-level rise include shoreline erosion, saltwater intrusion into groundwater aquifers, inundation of wetlands and estuaries, and threats to cultural and historic resources as well as infrastructure. Predicted accelerated global sea-level rise has generated a need in coastal geology to determine the likely response of a coastline to sea-level rise. However, an accurate and quantitative approach to predicting coastal change is difficult to establish. Even the kinds of data necessary to predict shoreline response are the subject of scientific debate. A number of predictive approaches have been proposed (National Research Council, 1990 and 1995), including:

1. extrapolation of historical data (e.g., coastal erosion rates),

2. static inundation modeling,

3. application of a simple geometric model (e.g., the Bruun Rule),

4. application of a sediment dynamics/budget model, or

5. Monte Carlo (probabilistic) simulation based on parameterized physical forcing variables.

However, each of these approaches has inadequacies or can be invalid for certain applications (National Research Council, 1990). Additionally, shoreline response to sea-level change is further complicated by human modification of the natural coast such as beach nourishment projects, and engineered structures such as seawalls, 
revetments, groins, and jetties. Understanding how a natural or modified coast will respond to sea-level change is essential to preserving vulnerable coastal resources.

The primary challenge in predicting shoreline response to sea-level rise is quantifying the important variables that contribute to coastal evolution in a given area. In order to address the multi-faceted task of predicting sea-level rise impact, the USGS has implemented a methodology to identify areas that may be most vulnerable to future sea-level rise (see Hammar-Klose and Thieler, 2001). This technique uses different ranges of vulnerability (low to very high) to describe a coast's susceptibility to physical change as sea level rises. The vulnerability index determined here focuses on six variables that strongly influence coastal evolution:

1. Geomorphology

2. Historical shoreline change rate

3. Regional coastal slope

4. Relative sea-level change

5. Mean significant wave height

6. Mean tidal range

These variables can be divided into two groups: 1) geologic variables and 2) physical process variables. The geologic variables are geomorphology, historic shoreline change rate, and coastal slope; they account for a shoreline's relative resistance to erosion, long-term erosion/accretion trend, and its susceptibility to flooding, respectively. The physical process variables include significant wave height, tidal range, and sea-level change, all of which contribute to the inundation hazards of a particular section of coastline over time scales from hours to centuries. A relatively simple vulnerability ranking system (Table 1 ) allows the six variables to be incorporated into an equation that produces a coastal vulnerability index (CVI). The CVI can be used by scientists and park managers to evaluate the likelihood that physical change may occur along a shoreline as sea level continues to rise.

Additionally, NPS staff will be able to incorporate information provided by this vulnerability assessment technique into general management plans.

\section{Data Ranking}

Table 1 shows the six variables described in the Introduction, which include both quantitative and qualitative information. The five quantitative variables are assigned a vulnerability ranking based on their actual values, whereas the non-numerical geomorphology variable is ranked qualitatively according to the relative resistance of a given landform to erosion. Shorelines with erosion/accretion rates between -1.0 and $+1.0 \mathrm{~m} / \mathrm{yr}$ are ranked as being of moderate vulnerability in terms of that particular variable. Increasingly higher erosion or accretion rates are ranked as correspondingly higher or lower vulnerability. Regional coastal slopes range from very high vulnerability, $<4.59$ percent, to very low vulnerability at values $>14.7$ percent. The rate of relative sea-level change is ranked using the modern rate of eustatic rise $(1.8 \mathrm{~mm} / \mathrm{yr})$ as very low vulnerability. Since this is a global or "background" rate common to all shorelines, the sea-level rise ranking reflects primarily local to regional isostatic or tectonic adjustment. Mean wave height contributions to vulnerability range from very low $(<1.1 \mathrm{~m})$ to very high $(>2.6 \mathrm{~m})$. Tidal range is ranked such that microtidal $(<1 \mathrm{~m})$ coasts are very high vulnerability, and macrotidal $(>6 \mathrm{~m})$ coasts are very low vulnerability.

\section{The Golden Gate National Recreation Area}

The sandy and cliffed coast of GGNRA lies along the Northern Coast of California (Figure 1). Stretching from Tomales Bay north of San Francisco to San Mateo County to the south, GGNRA is one of the largest urban parks in the world. Further, the geology of GGNRA and the San Francisco Bay Area is among the most complex and active geologic settings in the world (for more information on the geology of the San Francisco Bay region see: http://wrgis.wr.usgs.gov/wgmt/sfbay/index.html). The reason for the Bay region's geologic complexity is that it lies along the boundary of two major tectonic plates: the North American Plate and the Pacific Plate. Rocks and sediments along the park coast reflect the dynamic nature of the plate boundary and include cherts, pillow basalts, 
mélanges, volcanic rocks and ash, ocean floor sediments, and sediments that are presently being deposited as dunes, alluvium, and stream deposits (Chin and Graymer, 2001). These large tectonic plates slide past one another at an average rate of about 2 inches per year. However, movement along the plate boundary can occur in catastrophic bursts, such as in 1906 when a magnitude 7.7 earthquake (Waldo and others, 1993) shook San Francisco and moved the Pacific Plate 20 feet to the northwest along the San Andreas Fault. Other geologic hazards that can result in immediate and major coastal change within the San Francisco Bay region include landslides and tsunamis, but they are not directly addressed in the methodology of this report because their occurrence is episodic and their coastal impacts are difficult to predict

GGNRA was established in 1972, and NPS is preserving the vast natural, historical, and cultural resources within the urban park. Natural resources include over 1200 plant and animal species that exist in 19 distinct ecosystems. Cultural resources include archaeological sites, historic structures, and military forts (for more information on park resources see: http://www.nps.gov/goga/).

\section{Methodology}

In order to develop a database for a park-wide assessment of coastal vulnerability, data for each of the six variables mentioned above were gathered from state and federal agencies (Table 2). The database is based on that used by Thieler and Hammar-Klose (1999) and loosely follows an earlier database developed by Gornitz and White (1992). A comparable assessment of the sensitivity of the Canadian coast to sea-level rise is presented by Shaw and others (1998).

The database was constructed using a 1:24,000-scale shoreline for GGNRA that was obtained from the California Spatial Information Library (http://gis.ca.gov/). Data for each of the six variables (geomorphology, shoreline change, coastal slope, relative sea-level rise, significant wave height, and tidal range) were added to the shoreline attribute table using a 1-minute (approximately $1.5 \mathrm{~km}$ ) grid (Figure 2). Next each variable in each grid cell was assigned a vulnerability value from 1-5 ( 1 is very low vulnerability, 5 is very high vulnerability) based on the potential magnitude of its contribution to physical changes on the coast as sea level rises (Table 1).

\section{Geologic Variables}

The geomorphology variable expresses the relative erodibility of different landform types (Table 1). These data were derived from oblique aerial photography of the California coast (http://www.californiacoastline.org/). In addition, field visits were made within accessible locations of the park to ground-truth the geomorphologic classification (Figure 3 and Figure 4). GGNRA contained several geomorphology types, including low to very low vulnerability rock cliffs, moderate vulnerability alluvium and unconsolidated cliffs with beaches, high vulnerability engineered and gravel beaches, and very high vulnerability sand beaches (Figures 3 , 4, and 5). For locations with multiple geomorphologic types within a 1-minute section of coastline, the dominant morphology type was chosen to represent that section of coast.

Shoreline erosion and accretion rates for GGNRA were calculated from data provided by the USGS National Assessment of Coastal Change Hazards project (Table 2) (Hapke and others, unpub. data). Shoreline rates of change (m/yr) were calculated at $50 \mathrm{~m}$ intervals (transects) along the coast using Digital Shoreline Analysis System (DSAS) software (http://woodshole.er.usgs.gov/project-pages/dsas/) to derive the rate of shoreline change for historic shorelines from 1880 -1998. The change rates for each transect within a 1-minute grid cell were averaged to determine the shoreline change value used here, with positive numbers indicating accretion and negative numbers indicating erosion. Shoreline change rates within GGNRA mostly fell within $+1--1 \mathrm{~m} / \mathrm{yr}$ (moderate vulnerability) with a few small areas of high vulnerability (-1- $-2 \mathrm{~m} / \mathrm{yr}$ ) (Figure 6). Historic shorelines were not available for Alcatraz Island, Angel Island, and Tomales Bay, therefore, the moderate vulnerability category was assigned to these areas because 1) the majority of shoreline change rates for GGNRA fell within the moderate vulnerability category ( $+1--1 \mathrm{~m} / \mathrm{yr}$ ), and 2) much of the geomorphology of the shoreline in these areas is consolidated and is not likely to experience significant change within 1 year. 
The determination of regional coastal slope is an indication of the relative vulnerability to inundation and the potential rapidity of shoreline retreat because low-sloping coastal regions should retreat faster than steeper regions (Pilkey and Davis, 1987). The regional slope of the coastal zone was calculated from a grid of topographic and bathymetric elevations extending $5 \mathrm{~km}$ landward and seaward of the shoreline. Elevation data were obtained from the National Geophysical Data Center (NGDC) as gridded topographic and bathymetric elevations at 0.1-meter vertical resolution for 1-minute grid cells. Regional coastal slopes for GGNRA fall within the very low to very high vulnerability category $(<4.55 \%$ - $>14.7 \%)$ (Figure 7$)$.).

\section{Physical Process Variables}

The relative sea-level change variable is derived from the change in annual mean water elevation over time as measured at tide gauge stations along the coast. The rate of sea-level rise for San Francisco (post- 1906 earthquake), CA is $2.13+/-0.14 \mathrm{~mm} / \mathrm{yr}$ based on 94 years of data, and the value for Point Reyes is $2.51+/-1.27$ $\mathrm{mm} / \mathrm{yr}$ based on 25 years of data and (Zervas, 2001). This variable inherently includes both eustatic sea-level rise as well as regional sea-level rise due to isostatic and tectonic adjustments of the land surface. Relative sea-level change data are a historical record, and thus portray only the recent sea-level trend ( $<150$ years). Relative sea-level rise for GGNRA falls within the moderate to low vulnerability categories based on water elevation data at San Francisco and Point Reyes (Figure 8).

Mean significant wave height is used here as a proxy for wave energy which drives coastal sediment transport. Wave energy is directly related to the square of wave height:

$$
E=1 / 8 \rho g H^{2}
$$

where $E$ is energy density, $H$ is wave height, $\rho$ is water density and $g$ is acceleration due to gravity. Thus, the ability to mobilize and transport coastal sediments is a function of wave height squared. In this report, we use hindcast nearshore mean significant wave height data for the period 1956-75 obtained from the U.S. Army Corps of Engineers Wave Information Study (WIS) (See references in Hubertz and others, 1996). The model wave heights were compared to historical measured wave height data obtained from the NOAA National Data Buoy Center to ensure that model values were representative of the study area. For GGNRA, mean significant wave heights are between 0.1 and $2.5 \mathrm{~m}$, which represents very low to high vulnerability (Figure 9).

Tidal range is linked to both permanent and episodic inundation hazards. Tide range data were obtained from NOAA/NOS published benchmarks from Ocean Beach, Tomales Bay, Bolinas Lagoon, Point Bonita, Alcatraz Island, and Half Moon Bay. Mean tidal range is between 1.1 and $1.3 \mathrm{~m}$; therefore GGNRA was classified as high vulnerability (1.0 - 2.0 meters) with respect to tidal range (Figure 10$)$.

\section{Coastal Vulnerability Index}

The coastal vulnerability index (CVI) presented here is the same as that used in Thieler and Hammar-Klose (1999) and is similar to that used in Gornitz and others (1994), as well as to the sensitivity index employed by Shaw and others (1998). The CVI allows the six variables to be related in a quantifiable manner that expresses the relative vulnerability of the coast to physical changes due to future sea-level rise. This method yields numerical data that cannot be equated directly with particular physical effects. It does, however, highlight areas where the various effects of sea-level rise may be the greatest. Once each section of coastline is assigned a vulnerability value for each specific data variable, the coastal vulnerability index (CVI) is calculated as the square root of the product of the ranked variables divided by the total number of variables;

$$
\mathrm{CVI}=\sqrt{\frac{\left(a^{*} b^{*} c^{*} d^{*} e^{*} f\right)}{6}}
$$


where, $\mathrm{a}=$ geomorphology, $\mathrm{b}=$ shoreline erosion/accretion rate, $\mathrm{c}=$ coastal slope, $\mathrm{d}=$ =relative sea-level rise rate, $\mathrm{e}=$ mean significant wave height, and $\mathrm{f}=$ mean tide range. The calculated CVI value is then divided into quartile ranges to highlight different vulnerabilities within the park. The CVI ranges (low - very high) reported here apply specifically to GGNRA, and are not comparable to CVI ranges in other parks where the CVI has been employed (i.e. very high vulnerability means the same among parks; it's the numeric values that differ, such that a numeric value that equals very high vulnerability in one park may equal moderate vulnerability in another). To compare vulnerability between coastal parks, the national-scale studies should be used (Thieler and Hammar-Klose, 1999, 2000a, and 2000b). We feel this approach best describes and highlights the vulnerability specific to each park.

\section{Results}

The CVI values calculated for GGNRA range from 2.83 to 16.0 . The mean CVI value is 725 ; the mode is 4.0 and the median is 6.32. The standard deviation is 3.27 . The 25 th, 50 th, and 75 th percentiles are $4.4,6.25$ and 9.8 , respectively.

Figure 11 shows a map of the coastal vulnerability index for GGNRA. The CVI scores are divided into low, moderate, high, and very high-vulnerability categories based on the quartile ranges and visual inspection of the data. CVI values below 4.4 are assigned to the low vulnerability category. Values from 4.4 to 6.25 are considered moderate vulnerability. High-vulnerability values lie between 6.26 and 9.8. CVI values above 9.8 are classified as very high vulnerability. Figure 12 shows the percentage of GGNRA shoreline in each vulnerability category. Nearly $95 \mathrm{~km}$ (59 miles) of shoreline is evaluated along GGNRA. Of this total, twenty-four percent of the mapped shoreline is classified as being at very high vulnerability due to future sea-level rise. Twenty-six percent is classified as high vulnerability, twenty-six percent as moderate vulnerability, and twenty-four percent as low vulnerability.

\section{Discussion}

The data within the coastal vulnerability index (CVI) show variability at different spatial scales (Figure 11). However, the ranked values for the physical process variables vary less over the extent of the shoreline. The value of the relative sea-level rise variable is between low and moderate vulnerability. The significant wave height vulnerability is very low to high. The tidal range is mostly high vulnerability (1.0-2.0 m) for all of GGNRA, with the exception of Bolinas Lagoon (very high vulnerability), and therefore contributes little to the variability of the CVI.

The geologic variables show the most spatial variability and thus have the most influence on CVI variability (Figure 11). Geomorphology in the park includes very high vulnerability sandy beach shoreline, high vulnerability gravel beaches and engineered structures, moderate vulnerability alluvium and unconsolidated cliffs, and low and very low vulnerability rock and cliff features (Figure 3 A-E and Figure 4 A-G). Vulnerability assessment based on shoreline change is mostly moderate vulnerability with a few small areas of high vulnerability (Figure 6). Regional coastal slope is in the very low to very high vulnerability range for GGNRA.

The most influential variables in the CVI are geomorphology, coastal slope, and mean significant wave height; therefore they may be considered the dominant factors controlling how GGNRA will evolve as sea level rises.

Although there is parkland along Tomales Bay that lies within the legislative boundary of GGNRA, the area is managed by Point Reyes National Seashore. From a GGNRA management perspective there was a need to create another coastal vulnerability map that excludes the Tomales bay region from the rest of the vulnerability assessment. The map result of this analysis is shown in Figure 13. This map is considered supplemental for park managers and Figure 11 displays the results of the CVI analysis that this report is based upon. 


\section{Conclusions}

The coastal vulnerability index (CVI) provides insight into the relative potential of coastal change due to future sea-level rise. The maps and data presented here can be viewed in at least two ways:

1) as an indication of where physical changes are most likely to occur as sea level continues to rise; and

2) as a planning tool for the GGNRA.

As ranked in this study, geomorphology, regional coastal slope, and mean significant wave height play the largest role in determining the spatial variability of the CVI for GGNRA. Shoreline change, relative sea-level rise, and tidal range vary less spatially.

GGNRA preserves a dynamic natural environment, which must be understood in order to be managed properly. The CVI is one way that park managers can assess objectively the natural factors that contribute to the evolution of the coastal zone, and thus how the park may evolve in the future.

\section{References}

Chin, J.L., and Graymer, R.W., 2001, Regional Setting, in H. Karl, J. Chin, E. Uebuer, P. Stauffer, and J. Hendley II, eds., Beyond the GGNRA - oceanography, geology, biology, and environmental issues in the Gulf of the Farallones: U.S. Geological Survey Circular 1198, p. 8-11.

Douglas, B.C., 1997, Global sea rise, a redetermination: Surveys in Geophysics, v. 18, p. 279-292.

Gornitz, V., and White, T.W., 1992, A coastal hazards database for the U.S. West Coast: ORNL/CDIAC-81, NDP-043C, Oak Ridge National Laboratory, Oak Ridge, Tenn.

Gornitz, V.M., Daniels, R.C., White, T.W., and Birdwell, K.R., 1994, The development of a coastal vulnerability assessment database, vulnerability to sea-level rise in the U.S. southeast: Journal of Coastal Research, Special Issue No. 12, p. 327-338.

Hammar-Klose, E.S., and Thieler, E.R., 2001, Coastal vulnerability to sea-level rise; A preliminary database for the U.S. Atlantic, Pacific, and Gulf of Mexico coasts: U.S. Geological Survey, Digital Data Series, DDS-68, CD-ROM. Online

Hubertz, J.M., Thompson, E.F., and Wang, H.V., 1996, Wave Information Studies of U.S. coastlines, Annotated bibliography on coastal and ocean data assimilation: WIS Report 36, U.S. Army Engineer Waterways Experiment Station, Vicksburg, 31 p.

IPCC (Intergovernmental Panel on Climate Change), 2001, Climate Change 2001, in Houghton, J.T., Ding, Y., Griggs, D.J., Noguer, M., van der Linden, P.J., and Xiaosu, D., eds., The Scientific Basis; Contribution of Working Group I to the Third Assessment Report of the Intergovernmental Panel on Climate Change (IPCC): Cambridge, University Press, U.K., 944 p. (Also available at http://www.ipcc.ch/)

National Research Council, 1990, Managing Coastal Erosion, Washington: National Academy Press, 163 p.

National Research Council, 1995, Beach Nourishment and Protection, Washington: National Academy Press, 334 p.

Pilkey, O.H., and Davis, T.W., 1987, An analysis of coastal recession models, North Carolina coast, in Nummedal, D., Pilkey, O.H., and Howard, J.D., eds., Sea-level Fluctuation and Coastal Evolution: SEPM (Society for Sedimentary Geology) Special Publications No. 41, Tulsa, Okla., p. 59-68.

Shaw, J., Taylor, R.B., Forbes, D.L., Ruz, M.H., and Solomon, S., 1998, Sensitivity of the Canadian Coast to Sea-Level Rise: Geological Survey of Canada Bulletin 505, $114 \mathrm{p}$.

Thieler, E.R., and Hammar-Klose, E.S., 1999, National assessment of coastal vulnerability to sea-level rise, U.S. Atlantic Coast: U.S. Geological Survey Open-File Report 99-593, 1 sheet.

Thieler, E.R., and Hammar-Klose, E.S., 2000a, National assessment of coastal vulnerability to sea-level rise, U.S. Pacific Coast: U.S. Geological Survey Open-File Report 00-178, 1 sheet.

Thieler, E.R., and Hammar-Klose, E.S., 2000b, National assessment of coastal vulnerability to sea-level rise, U.S. Gulf of Mexico Coast: U.S. Geological Survey Open-File Report 00-179, 1 sheet.

Waldo, D.J., Kanamori, H., and Helmberger, D.V., 1993, Source study of the 1906 San Francisco Earthquake: Bulletin of the Seismology Society of America, v. 83, p. 981-1019.

Zervas, C., 2001, Sea Level Variations of the United States 1854-1999: NOAA Technical Report NOS CO-OPS 36, 201 p. 


\section{List of Figures}

Figure 1. Location of GGNRA, along the San Francisco Bay Region, California.

Figure 2. Shoreline grid for GGNRA. Each cell is approximately I-minute of shoreline and represents a shoreline segment for which each variable is defined.

Figure 3. Geomorphologic features within the northern section of GGNRA. The figure at the top left provides an index for photos A-E. A) Stinson Beach is classified as very high vulnerability. B) Muir beach is classified as moderate vulnerability because it is a large pocket that is mostly backed by cliffs. C) This photo shows Rodeo Beach near Forth Cronkhite, just north of Point Bonita. This barrier beach and associated lagoon are classified as very high vulnerability. D) The high steep rock cliffs at Point Bonita are classified as very low vulnerability. E) A view of Point Diablo from Point Bonita, most of this area is classified as low - very low vulnerability depending on cliff height and presence or absence of pocket beaches. The majority of the coastline of GGNRA can be viewed from an oblique aerial photo perspective through the following Web site: http://www.californiacoastline.org/.

Figure 4. Geomorphologic features within the southern section of GGNRA. The figure at the top left provides an index for photos A-G. A) Alcatraz Island is classified as low vulnerability because of its relatively low rock cliffs. B) The Fort Mason shoreline is classified as high vulnerability because it is low elevation and heavily engineered. C) The beach at Crissy Field is classified as very high vulnerability. D) The Sutro baths are high vulnerability and they are adjacent to the very low vulnerability cliffs at Lands End. E) Ocean Beach is classified as very high vulnerability. F) The Fort Funston shoreline is classified as moderate vulnerability because the beach is backed by unconsolidated cliffs.

Figure 5. Coastal Geomorphology for GGNRA. The colored shoreline represents the variations in coastal geomorphology within the park. The very high vulnerability geomorphology is mostly low elevation sand beaches and estuary mouths. High vulnerability geomorphology includes gravel and cobble beaches or heavily engineered coastline inside San Francisco Bay. Moderate vulnerability geomorphology consists of alluvial fans and cliffs with sand beaches. Low vulnerability geomorphology includes low to medium cliffs and rock platforms, and very low vulnerability areas consist of mostly high vertical rock cliffs.

Figure 6. Shoreline change rates for GGNRA. The colored shoreline represents the rate of shoreline erosion or accretion. Most of GGNRA is moderate vulnerability $(-1 \mathrm{~m} / \mathrm{yr}-+1 \mathrm{~m} / \mathrm{yr})$ with respect to shoreline change; however, there are a few high vulnerability $(-1--2 \mathrm{~m} / \mathrm{yr})$ areas.

Figure 7. Regional coastal slope for GGNRA. The colored shoreline represents the regional slope of the land, $5 \mathrm{~km}$ landward and seaward of the shoreline. The highest vulnerability coastal slope areas are primarily within San Francisco. The lowest vulnerability coastal slope areas are to the north of San Francisco Bay or in Tomales Bay.

Figure 8. Rate of relative sea-level rise for GGNRA. The colored shoreline represents the ranked rate of rise for San Francisco and Point Reyes, CA. GGNRA is ranked as low and moderate vulnerability (along the Point Reyes peninsula) with respect to relative sea-level rise.

Figure 8. Rate of relative sea-level rise for GGNRA. The colored shoreline represents the ranked rate of rise for San Francisco and Point Reyes, CA. GGNRA is ranked as low and moderate vulnerability (along the Point Reyes peninsula) with respect to relative sea-level rise.

Figure 9. Mean Significant Wave Height for GGNRA. The colored shoreline represents the ranked mean significant wave height within the park. The highest wave heights are loc ated within the southern part of GGNRA where the dominant northwest waves approach uninterrupted. Wave heights are lowest in Tomales Bay and along the Marin headland shore where the coast is sheltered from the dominant wave approach.

Figure 10. Mean Tidal Range for GGNRA. The colored shoreline represents the ranked mean tidal range for GGNRA. GGNRA is ranked mostly as high vulnerability with the exception of Bolinas Lagoon, which is very high vulnerability.

Figure 11. Relative Coastal Vulnerability for GGNRA. The colored shoreline represents the relative coastal vulnerability index (CVI) determined from the six variables. The very high vulnerability shoreline is generally located along sandy beaches where significant wave heights are highest and regional coastal slope is shallow. The lower vulnerability shoreline is located along rock cliffs mostly along the northern part of GGNRA where wave heights are lower and coastal slope is steep.

Figure 12. Percentage of GGNRA shoreline in each CVI category. 
Figure 13. A supplemental CVI was calculated for GGNRA that excluded park lands along Tomales Bay that are managed by Point Reyes National Seashore. This figure was created to further assist park managers, and to display the Coastal Vulnerability ranges, as they would be if Tomales Bay were not a part of the vulnerability assessment. 


\section{Tables}

Table 1. Ranges for Vulnerability Ranking of Variables on the U.S. Pacific Coast.

Table 2. Sources of Data 


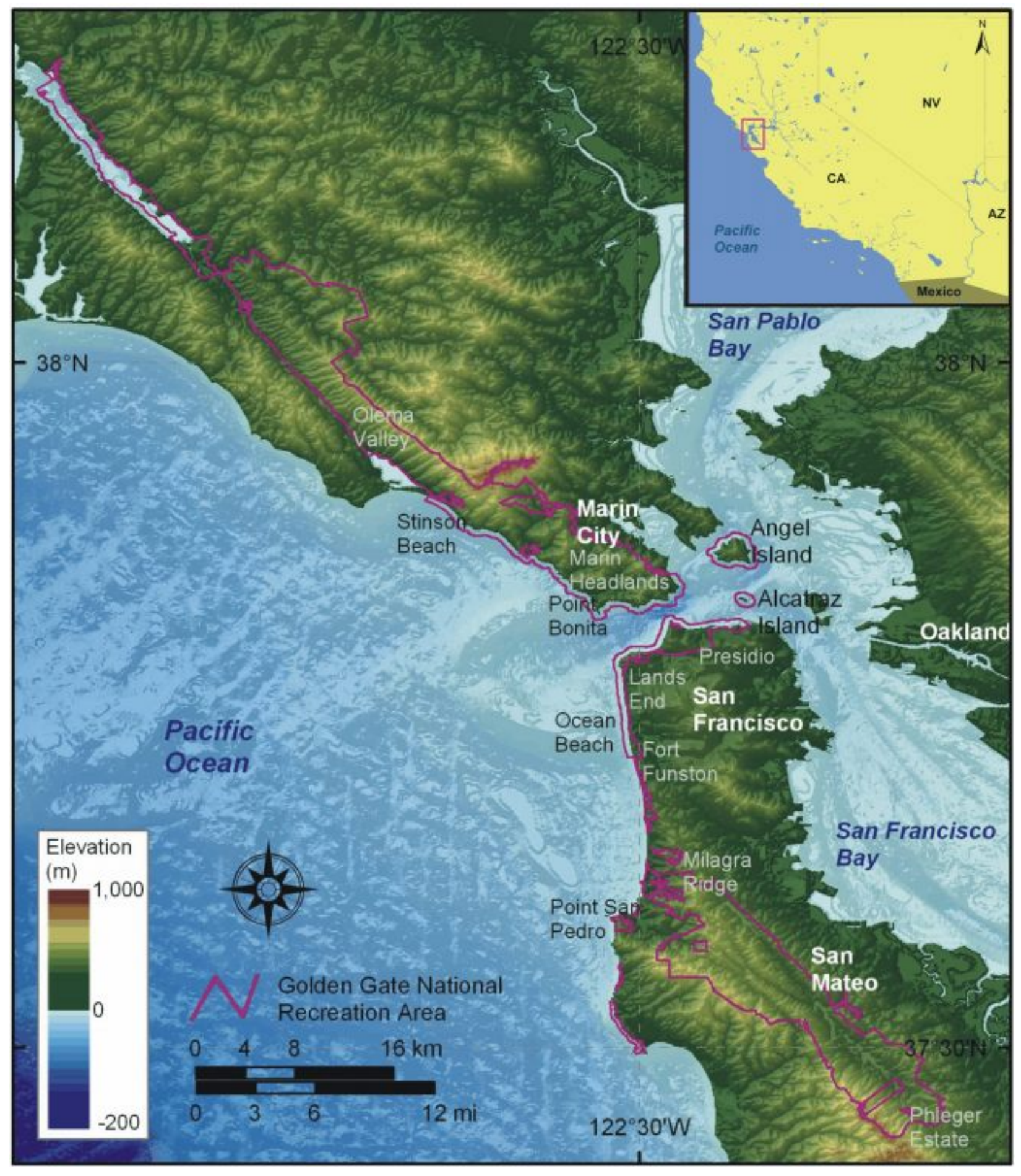

Figure 1. Location of GGNRA, along the San Francisco Bay Region, California. 


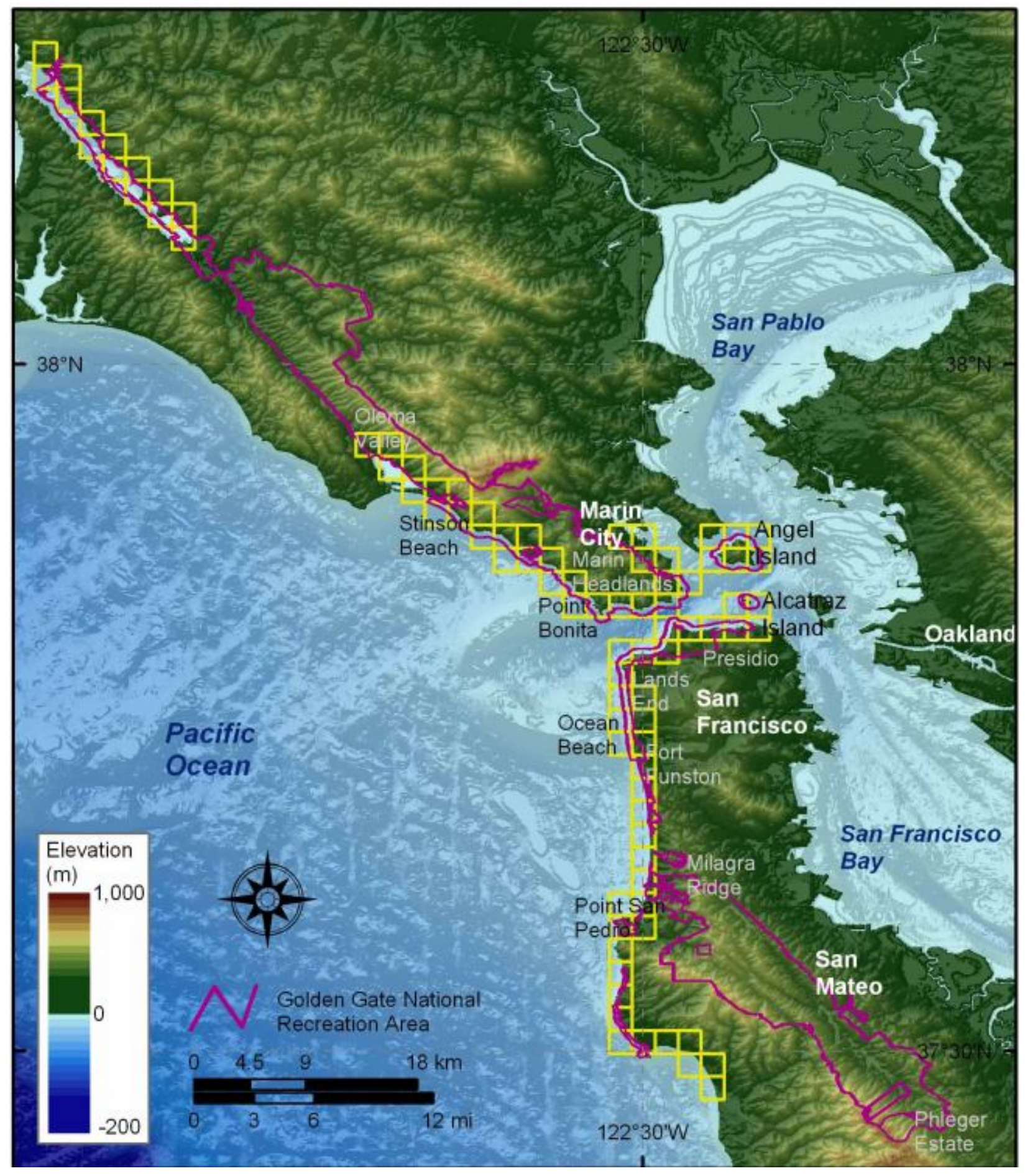

Figure 2. Shoreline grid for GGNRA. Each cell is approximately I-minute of shoreline and represents a shoreline segment for which each variable is defined. 


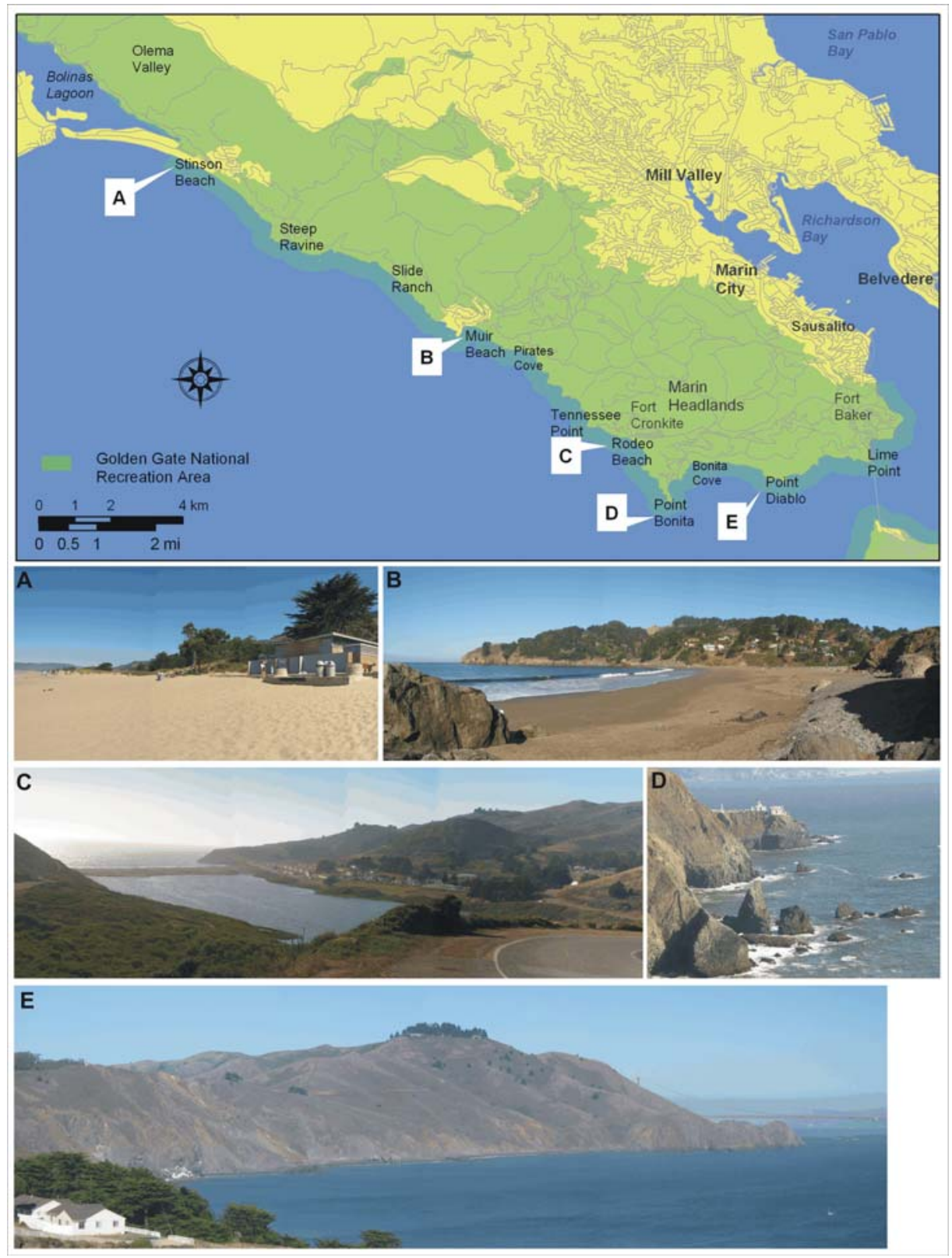

Figure 3. Geomorphologic features within the northern section of GGNRA. The figure at the top left provides an index for photos A-E.

A) Stinson Beach is classified as very high vulnerability.

B) Muir beach is classified as moderate vulnerability because it is a large pocket that is mostly backed by cliffs.

C) This photo shows Rodeo Beach near Forth Cronkhite, just north of Point Bonita. This barrier beach and associated lagoon are classified as very high vulnerability.

D) The high steep rock cliffs at Point Bonita are classified as very low vulnerability.

E) A view of Point Diablo from Point Bonita, most of this area is classified as low - very low vulnerability depending on cliff height and presence or absence of pocket beaches. The majority of the coastline of GGNRA can be viewed from an oblique aerial photo perspective through the following Web site: http://www.californiacoastline.org/. 

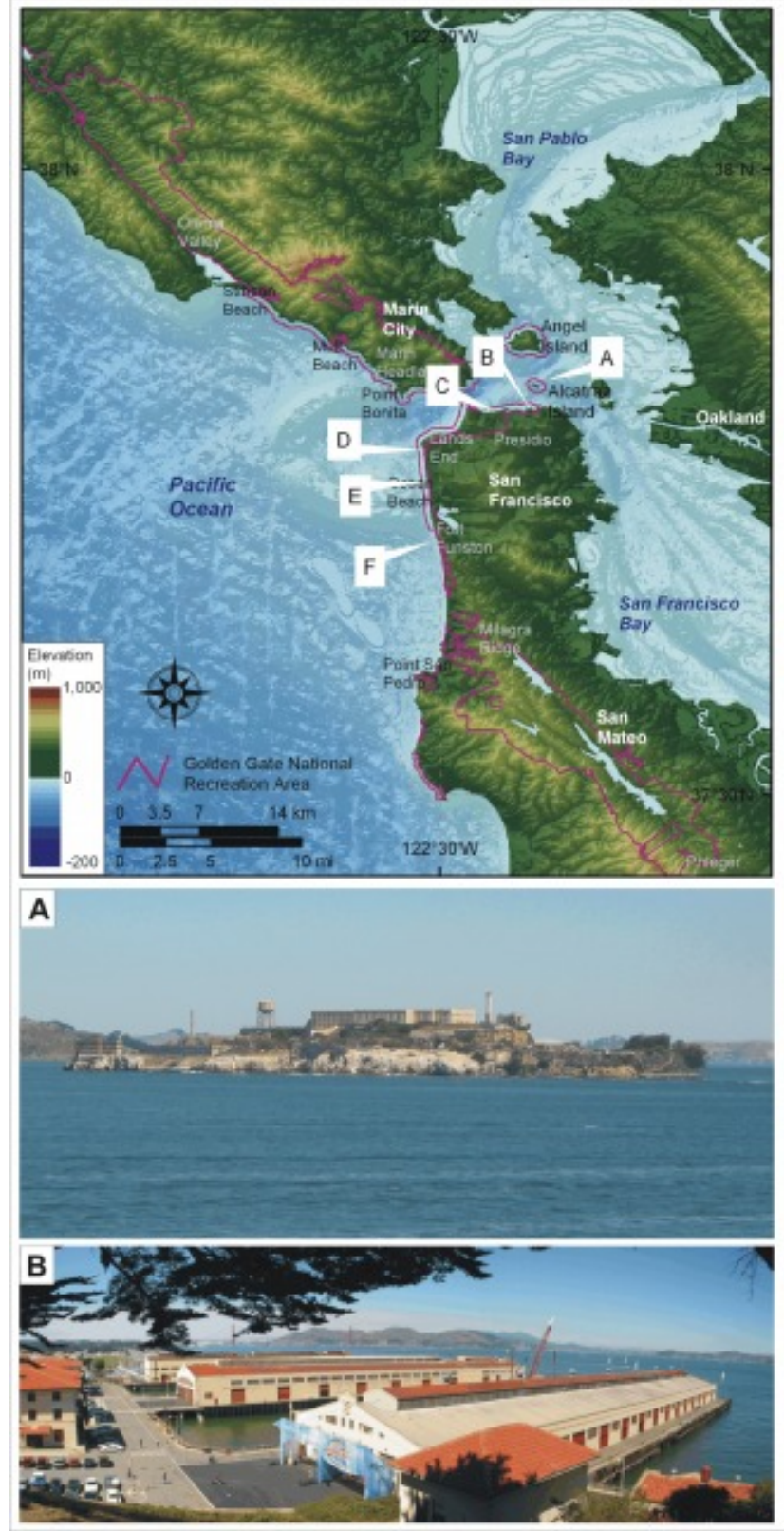
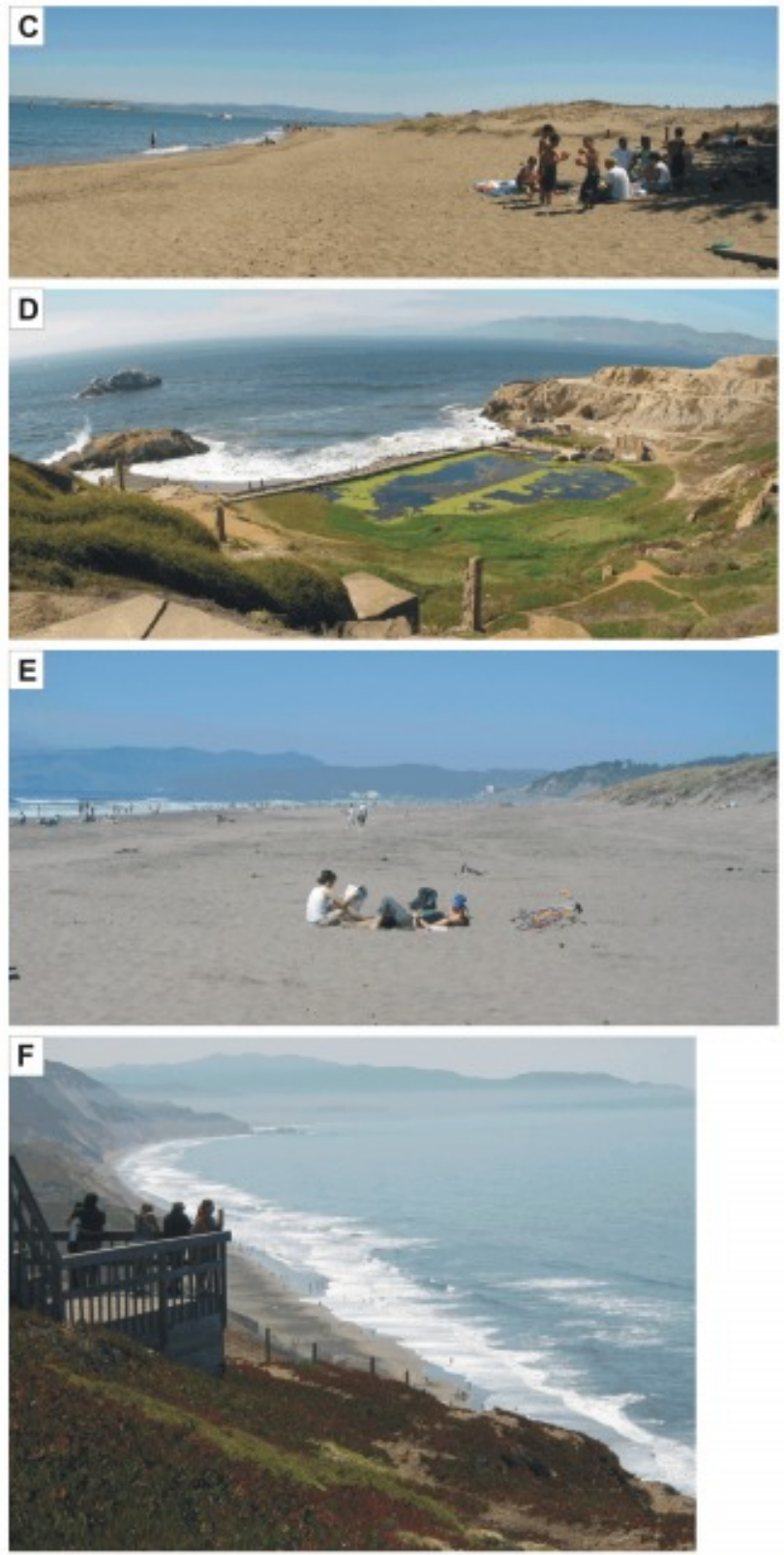

Figure 4. Geomorphologic features within the southern section of GGNRA. The figure at the top left provides an index for photos AG.

A) Alcatraz Island is classified as low vulnerability because of its relatively low rock cliffs.

B) The Fort Mason shoreline is classified as high vulnerability because it is low elevation and heavily engineered.

C) The beach at Crissy Field is classified as very high vulnerability.

D) The Sutro baths are high vulnerability and they are adjacent to the very low vulnerability cliffs at Lands End.

E) 0 cean Beach is classified as very high vulnerability. F) The Fort Funston shoreline is classified as moderate vulnerability because the beach is backed by unconsolidated cliffs. 


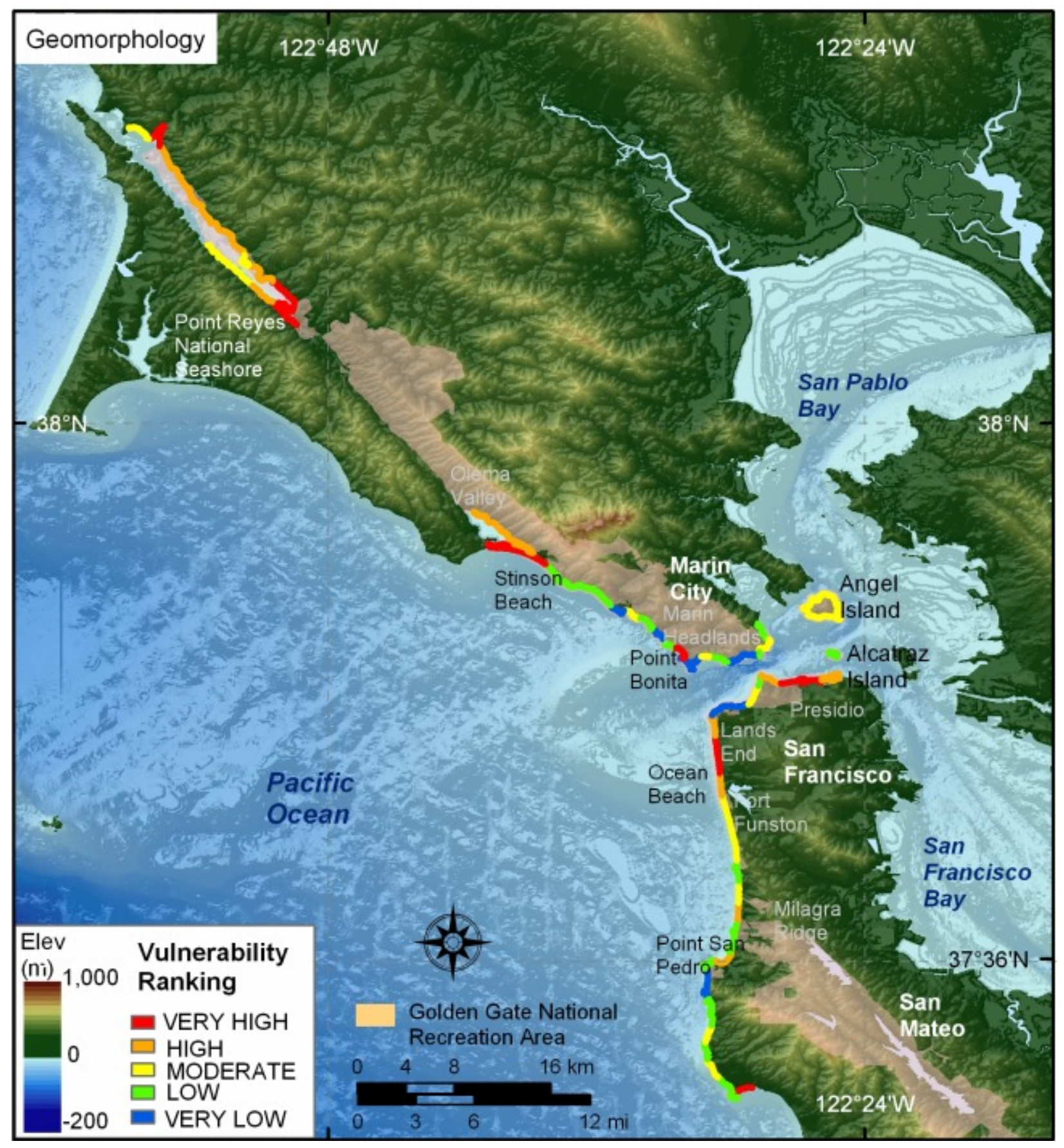

Figure 5. Coastal Geomorphology for GGNRA. The colored shoreline represents the variations in coastal geomorphology within the park. The very high vulnerability geomorphology is mostly low elevation sand beaches and estuary mouths. High vulnerability geomorphology includes gravel and cobble beaches or heavily engineered coastline inside San Francisco Bay. Moderate vulnerability geomorphology consists of alluvial fans and cliffs with sand beaches. Low vulnerability geomorphology includes low to medium cliffs and rock platforms, and very low vulnerability areas consist of mostly high vertical rock cliffs. 


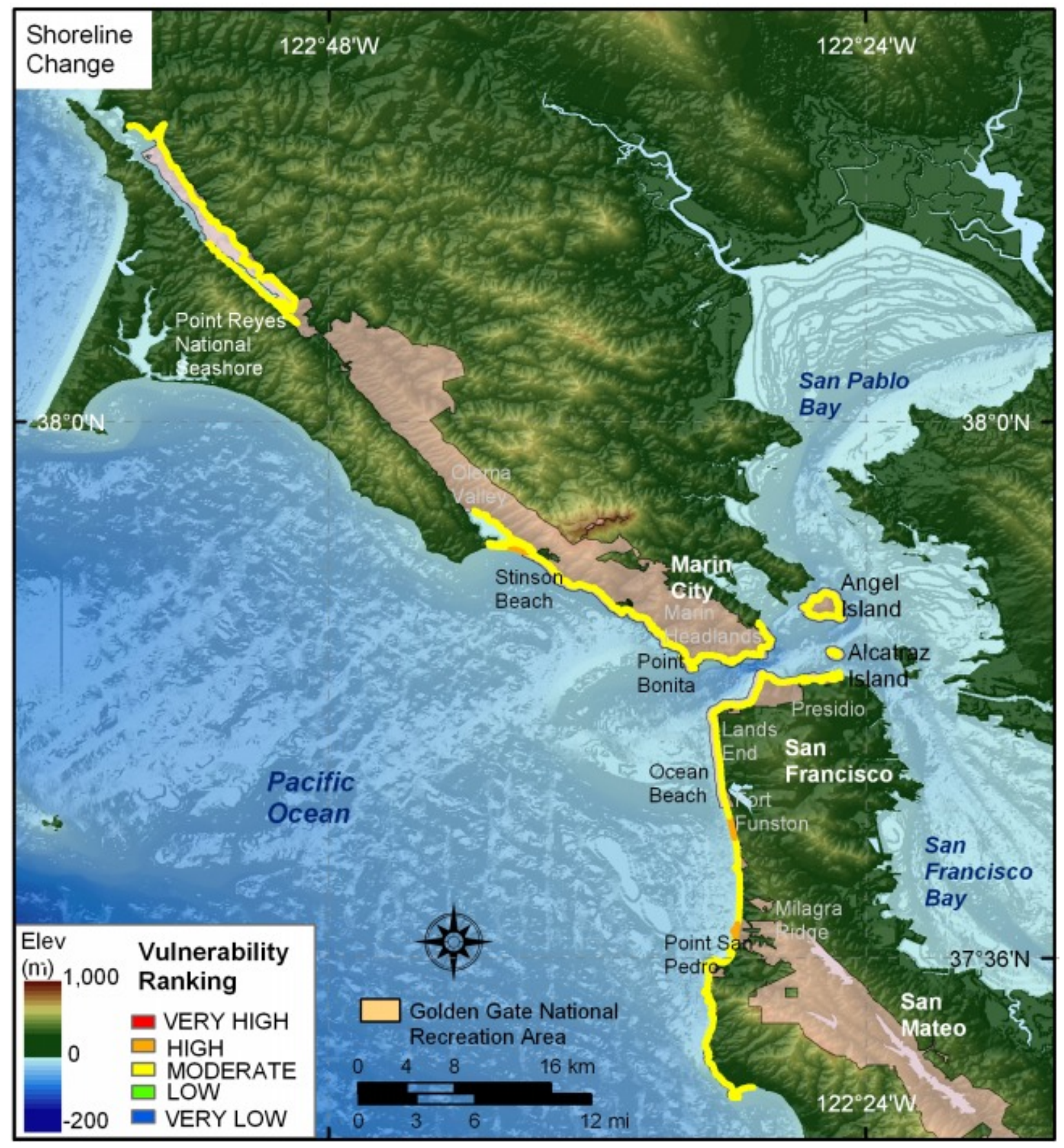

Figure 6. Shoreline change rates for GGNRA. The colored shoreline represents the rate of shoreline erosion or accretion. Most of GGNRA is moderate vulnerability $(-1 \mathrm{~m} / \mathrm{yr}-+1 \mathrm{~m} / \mathrm{yr})$ with respect to shoreline change; however, there are a few high vulnerability $(-1--2 \mathrm{~m} / \mathrm{yr})$ areas. 


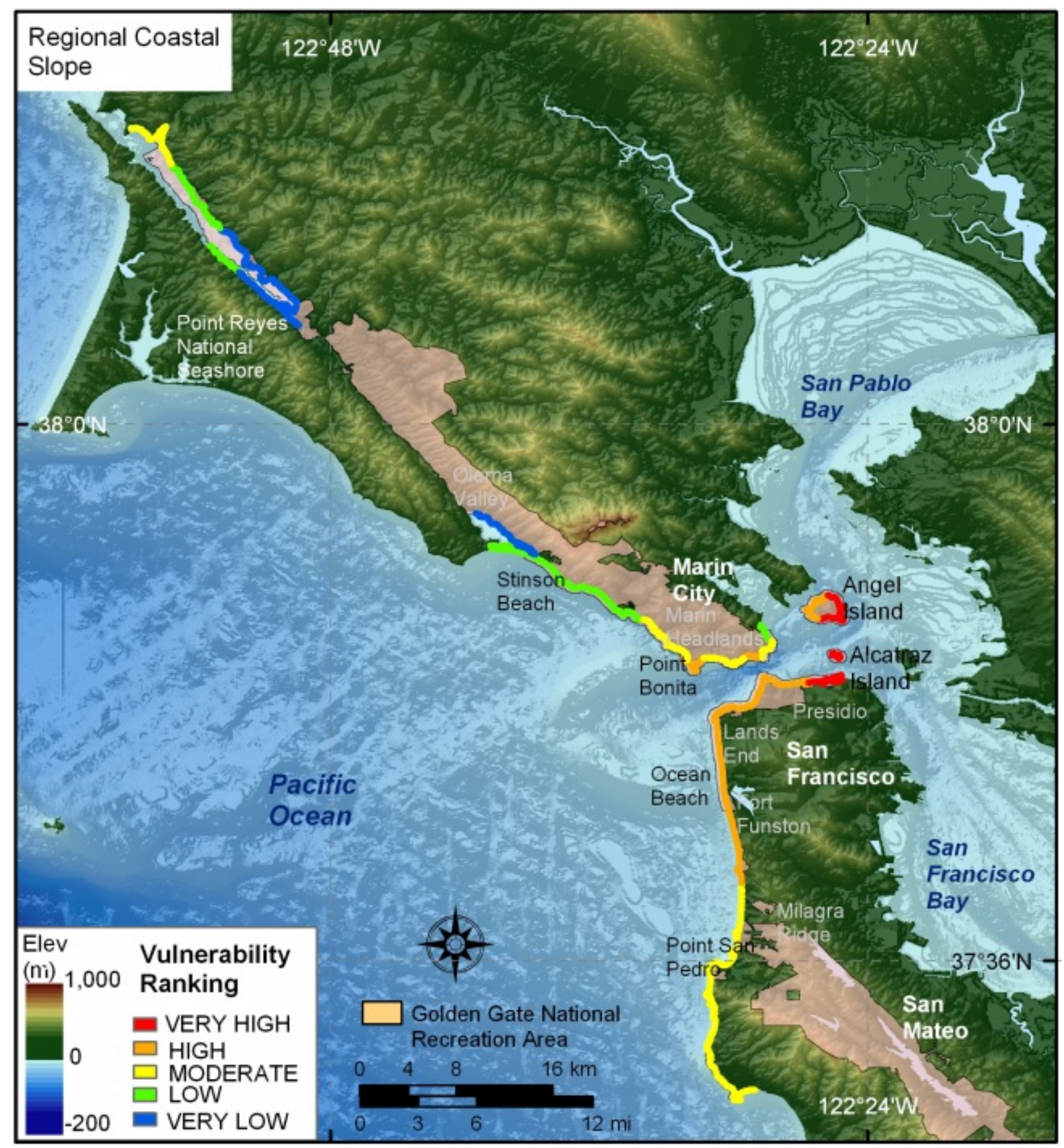

Figure 7. Regional coastal slope for GGNRA. The colored shoreline represents the regional slope of the land, $5 \mathrm{~km}$ landward and seaward of the shoreline. The highest vulnerability coastal slope areas are primarily within San Francisco. The lowest vulnerability coastal slope areas are to the north of San Francisco Bay or in Tomales Bay. 


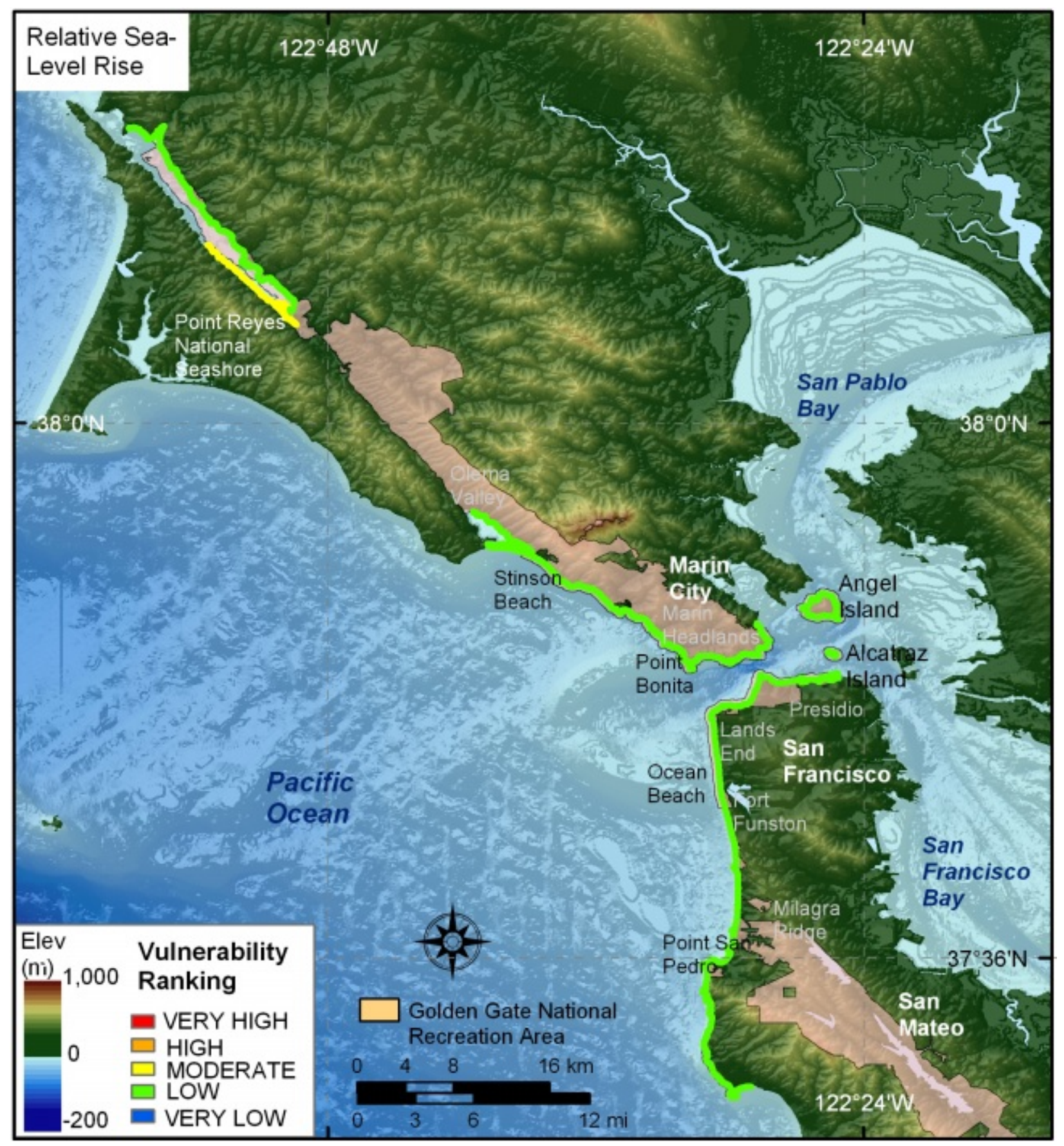

Figure 8. Rate of relative sea-level rise for GGNRA. The colored shoreline represents the ranked rate of rise for San Francisco and Point Reyes, CA. GGNRA is ranked as low and moderate vulnerability (along the Point Reyes peninsula) with respect to relative sea-level rise. 


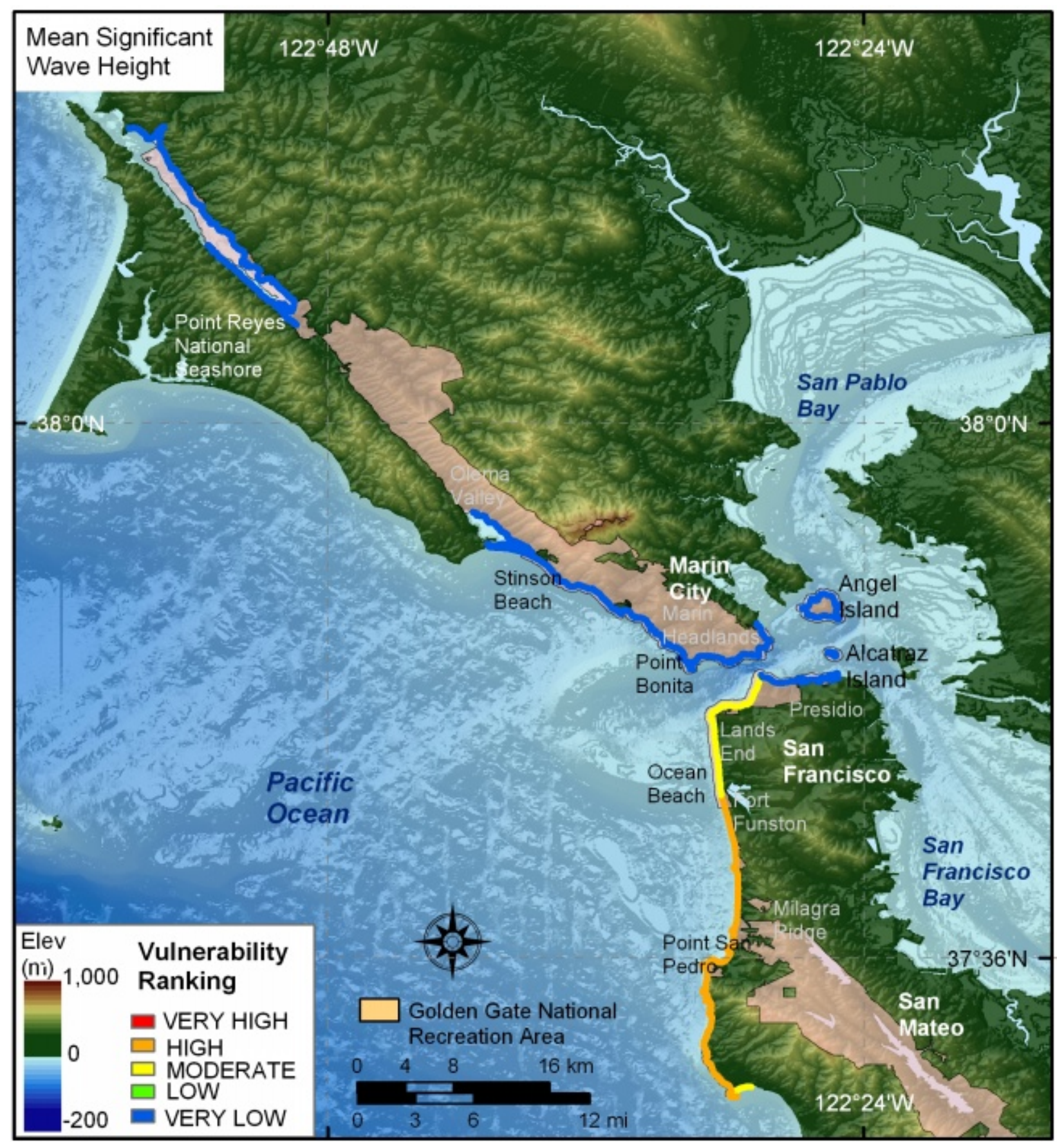

Figure 9. Mean Significant Wave Height for GGNRA. The colored shoreline represents the ranked mean significant wave height within the park. The highest wave heights are located within the southern part of GGNRA where the dominant northwest waves approach uninterrupted. Wave heights are lowest in Tomales Bay and along the Marin headland shore where the coast is sheltered from the dominant wave approach. 


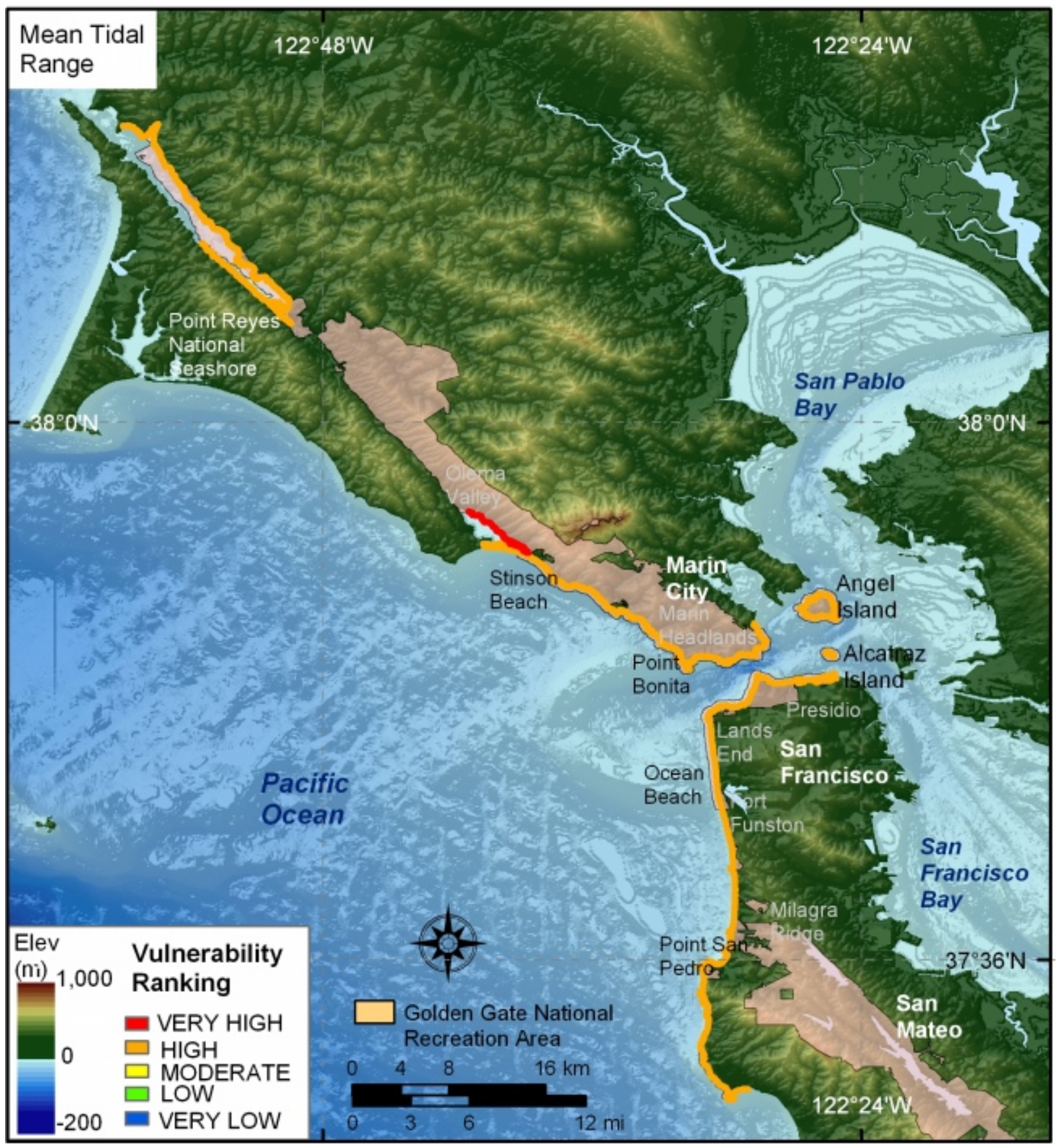

Figure 10. Mean Tidal Range for GGNRA. The colored shoreline represents the ranked mean tidal range for GGNRA. GGNRA is ranked mostly as high vulnerability with the exception of Bolinas Lagoon, which is very high vulnerability. 


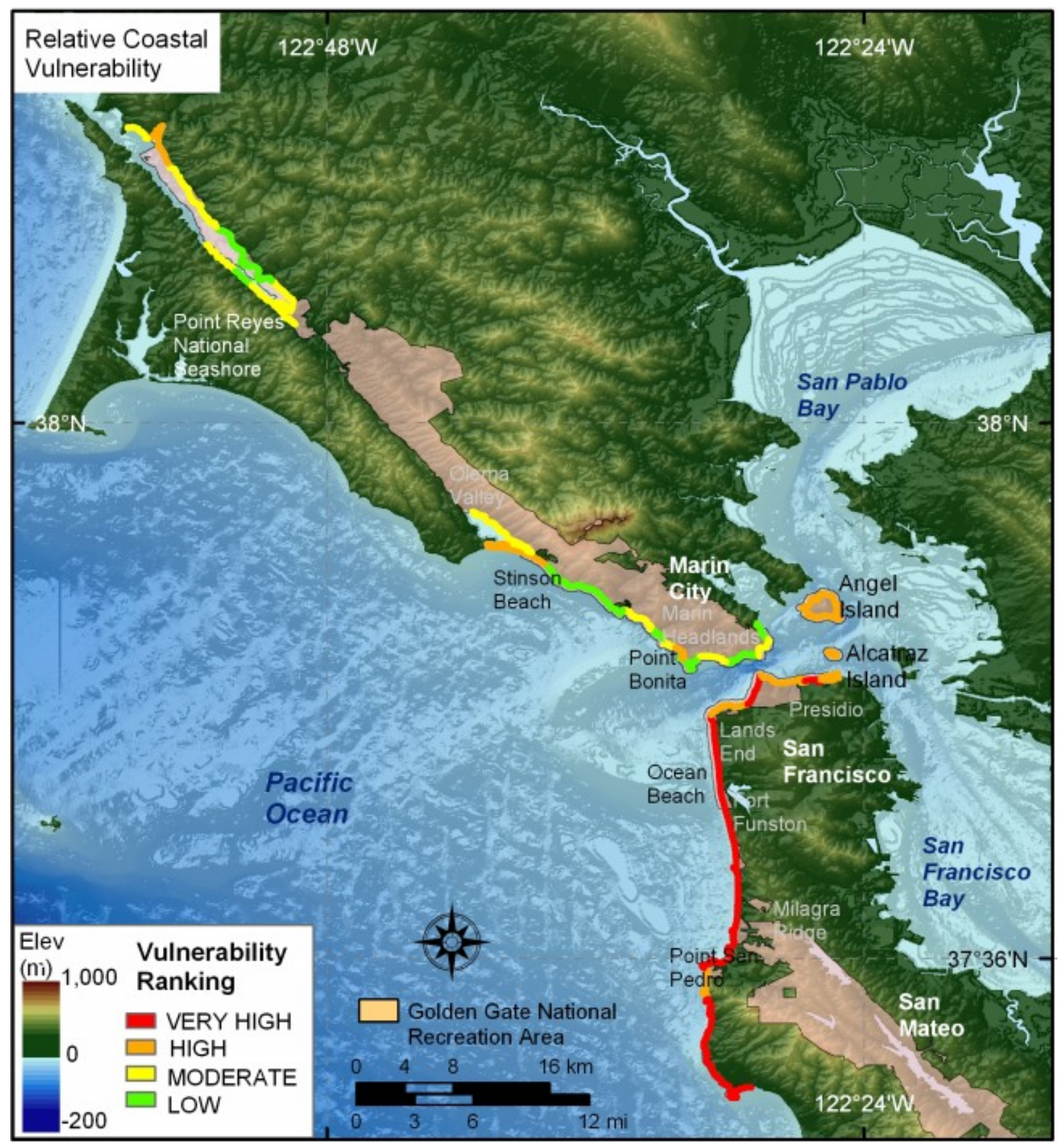

Figure 11. Relative Coastal Vulnerability for GGNRA. The colored shoreline represents the relative coastal vulnerability index (CVI) determined from the six variables. The very high vulnerability shoreline is generally located along sandy beaches where significant wave heights are highest and regional coastal slope is shallow. The lower vulnerability shoreline is located along rock cliffs mostly along the northern part of GGNRA where wave heights are lower and coastal slope is steep. 


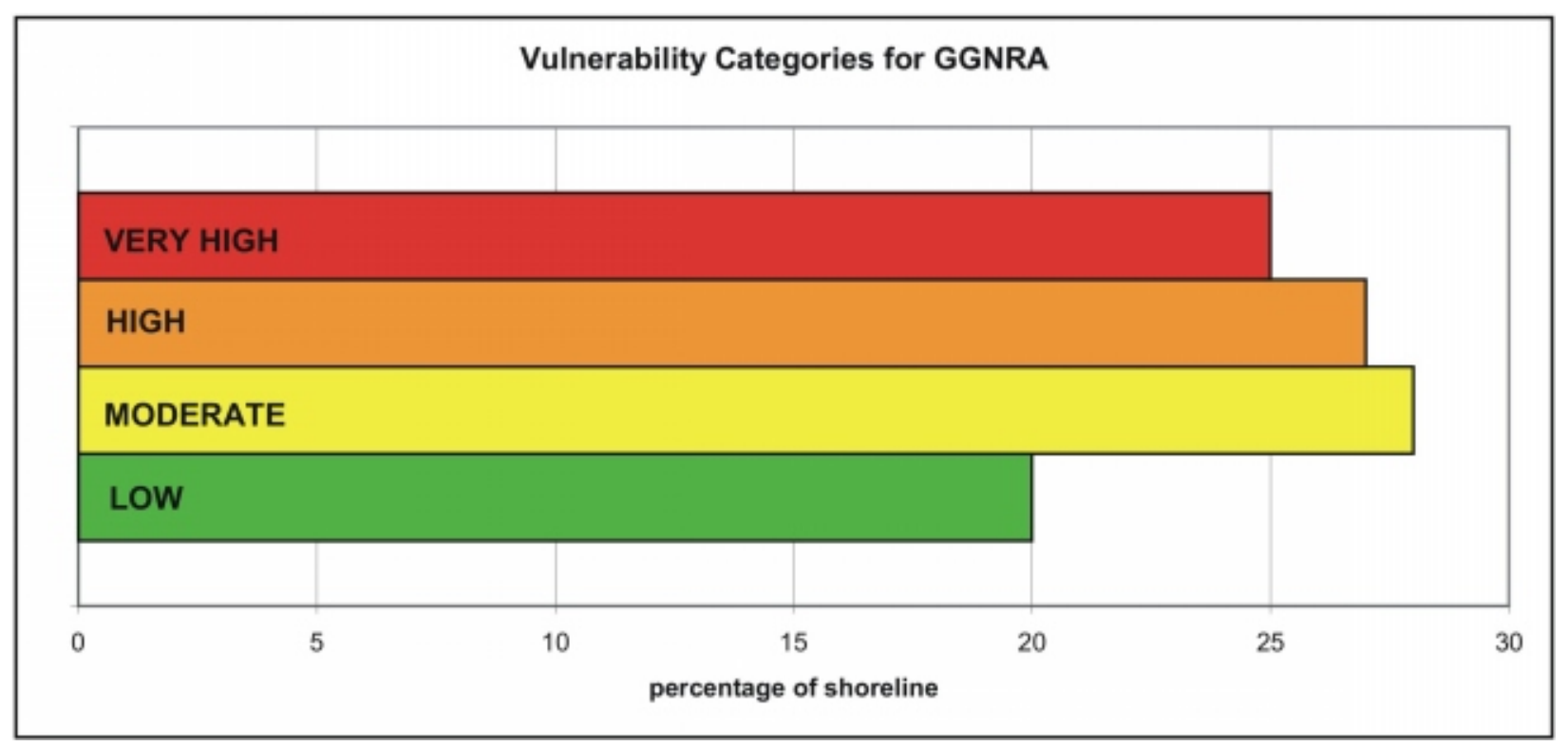

Figure 12. Percentage of GGNRA shoreline in each CVI category. 


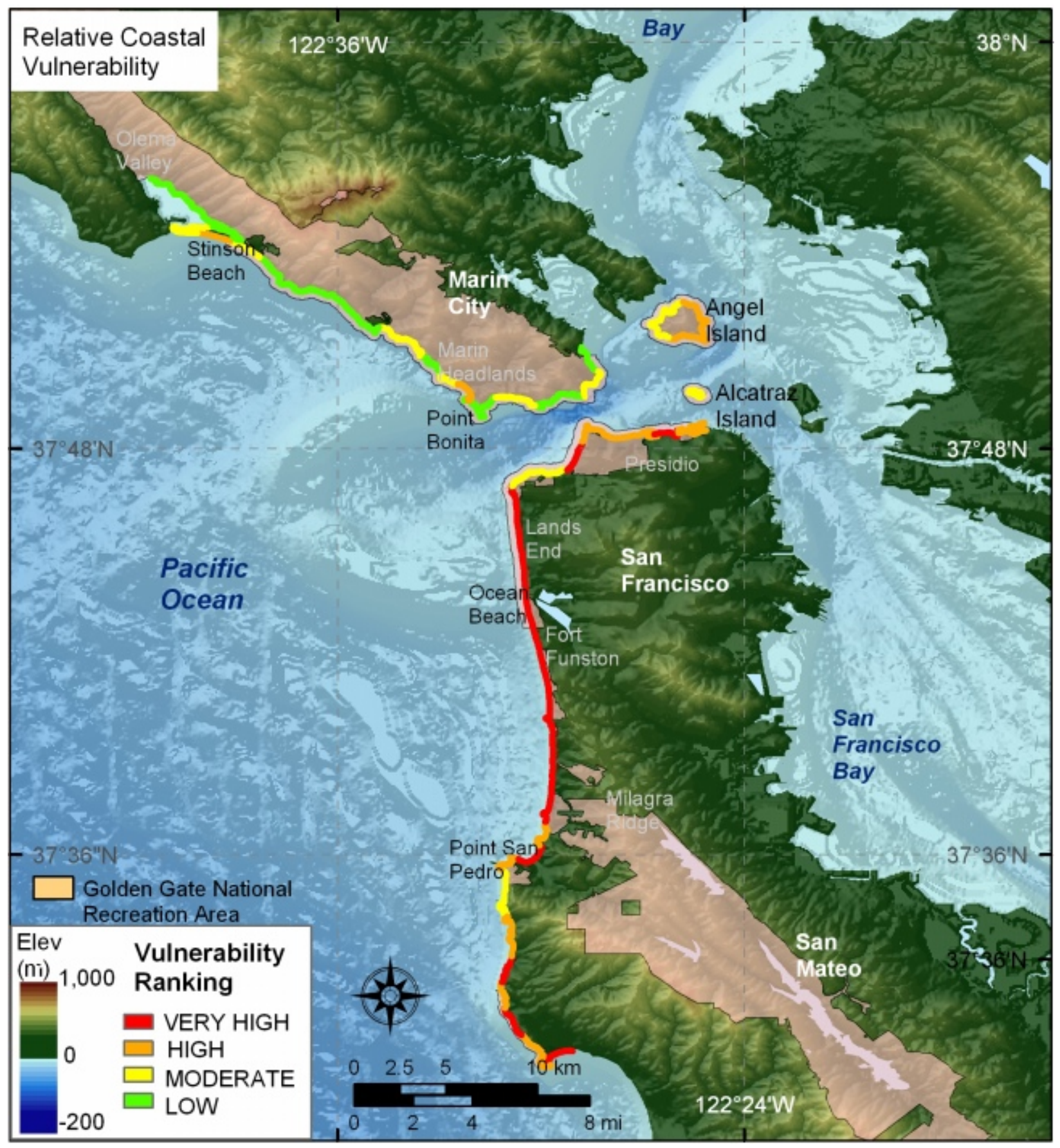

Figure 13. A supplemental CVI was calculated for GGNRA that excluded park lands along Tomales Bay that are managed by Point Reyes National Seashore. This figure was created to further assist park managers, and to display the Coastal Vulnerability ranges, as they would be if Tomales Bay were not a part of the vulnerability assessment.. 
Table 1. Ranges for Vulnerability Ranking of Variables on the U.S. Pacific Coast.

\begin{tabular}{|c|c|c|c|c|c|}
\hline Variables & $\begin{array}{c}\text { Very Low } \\
1\end{array}$ & $\begin{array}{c}\text { Low } \\
2\end{array}$ & $\begin{array}{c}\text { Moderate } \\
\quad 3\end{array}$ & $\begin{array}{l}\text { High } \\
4\end{array}$ & $\begin{array}{l}\text { Very High } \\
5\end{array}$ \\
\hline GEOMORPHOLOGY & $\begin{array}{l}\text { Rocky } \\
\text { cliffed } \\
\text { coasts, } \\
\text { Fjords }\end{array}$ & $\begin{array}{l}\text { Medium } \\
\text { cliffs, } \\
\text { Indented } \\
\text { coasts }\end{array}$ & $\begin{array}{l}\text { Low cliffs, } \\
\text { Glacial drift, } \\
\text { Alluvial } \\
\text { plains }\end{array}$ & $\begin{array}{c}\text { Cobble } \\
\text { Beaches, } \\
\text { Estuary, Lagoon }\end{array}$ & $\begin{array}{c}\text { Barrier beaches, Sand beaches, } \\
\text { Salt marsh, Mud flats, Deltas, } \\
\text { Mangrove, Coral reefs }\end{array}$ \\
\hline $\begin{array}{l}\text { SHORELINE EROSION/ } \\
\text { ACCRETION (m/yr) }\end{array}$ & $>2.0$ & 1.0 to 2.0 & -1.0 to 1.0 & -2.0 to -1.0 & $<-2.0$ \\
\hline OASTAL SLOPE (\%) & $>14.70$ & $10.90-14.69$ & $7.75-10.89$ & $4.60-7.74$ & $<4.59$ \\
\hline $\begin{array}{l}\text { RELATIVE SEA-LEVEL } \\
\text { CHANGE (mm/yr) }\end{array}$ & $<1.8$ & $1.8-2.5$ & $2.5-3.0$ & $3.0-3.4$ & $>3.4$ \\
\hline $\begin{array}{c}\text { MEAN WAVE HEIGHT } \\
\text { (m) }\end{array}$ & $<1.1$ & $1.1-2.0$ & $2.01-2.25$ & $2.26-2.6$ & $>2.6$ \\
\hline MEAN TIDE RANGE (m) & $>6.0$ & $4.0-6.0$ & $2.0-4.0$ & $1.0-2.0$ & $<1.0$ \\
\hline
\end{tabular}




\begin{tabular}{|c|c|c|}
\hline Variables & Source & $\begin{array}{c}\text { URL } \\
\text { (Not all sources are downloadable) }\end{array}$ \\
\hline GEOMORPHOLOGY & $\begin{array}{l}\text { An oblique aerial } \\
\text { photographic survey of the } \\
\text { California Coast }\end{array}$ & http://www.californiacoastline.org/ \\
\hline $\begin{array}{c}\text { SHORELINE } \\
\text { EROSION/ACCRETION } \\
(\mathrm{m} / \mathrm{yr})\end{array}$ & $\begin{array}{l}\text { Historical Shoreline } \\
\text { Change and Associated } \\
\text { Coastal Land Loss Along } \\
\text { the California Coast, U.S. } \\
\text { Geological Survey (Hapke } \\
\text { and others, unpub. data) }\end{array}$ & http://coastal.er.usgs.gov/shoreline-change/index.html \\
\hline COASTAL SLOPE (\%) & $\begin{array}{l}\text { NGDC Coastal Relief } \\
\text { Model Vol } 07\end{array}$ & http://www.ngdc.noaa.gov/mgg/coastal/coastal.html \\
\hline $\begin{array}{l}\text { RELATIVE SEA-LEVEL } \\
\text { CHANGE }(\mathrm{mm} / \mathrm{yr})\end{array}$ & $\begin{array}{l}\text { NOAA Technical Report } \\
\text { NOS CO-OPS } 36 \text { SEA } \\
\text { LEVEL VARIATIONS } \\
\text { OF THE UNITED } \\
\text { STATES 1854-1999 } \\
\text { (Zervas, 2001) }\end{array}$ & http://www.co-ops.nos.noaa.gov/publications/techrpt36doc.pdf \\
\hline $\begin{array}{l}\text { MEAN WAVE HEIGHT } \\
(\mathrm{m})\end{array}$ & $\begin{array}{l}\text { Pacific Coast WIS Data } \\
\text { and National Data Buoy } \\
\text { Center }\end{array}$ & $\begin{array}{l}\text { http://frf.usace.army.mil/wis/wis main.html } \\
\text { http://seaboard.ndbc.noaa.gov/ }\end{array}$ \\
\hline MEAN TIDE RANGE (m) & $\begin{array}{l}\text { NOAA/NOS CO-OPS } \\
\text { Historical Water Level } \\
\text { Station Index }\end{array}$ & http://www.co-ops.nos.noaa.gov/usmap.html \\
\hline
\end{tabular}

